\title{
Association of prohormone convertase 3 with membrane lipid rafts
}

\section{Blázquez, K Docherty and K I J Shennan}

Department of Molecular and Cell Biology, Institute of Medical Sciences, University of Aberdeen, Foresterhill, Aberdeen AB25 2ZD, UK

(Requests for offprints should be addressed to K I J Shennan; Email: k.i.shennan@abdn.ac.uk)

\begin{abstract}
Prohormone convertase $3(\mathrm{PC} 3)$ is a neuroendocrine-specific member of the subtilisin-kexin family, involved in the intracellular processing and maturation of prohormones and proneuropeptides. PC3 is synthesised as a proprotein that undergoes two different cleavages resulting in the mature PC3 and the enzymatically active $\mathrm{PC} 3 \Delta \mathrm{C}$. In vitro translated proPC 3 and proPC $3 \Delta \mathrm{C}$ bind to transGolgi network (TGN)/granule-enriched membranes from the At'T20 neuroendocrine cell line in a $\mathrm{pH}$-dependent manner suggesting both a dominant role for the pro-region in membrane association and that the $\mathrm{C}$-terminal region is not essential. However, while $\mathrm{PC} 3$ bound to membranes the majority of $\mathrm{PC} 3 \Delta \mathrm{C}$ did not, suggesting that either the pro-region or the $\mathrm{C}$-terminal region of $\mathrm{PC} 3$ is
\end{abstract}

required for membrane association. Removal of peripheral membrane proteins did not affect the binding properties of any of the in vitro translated proteins. Chromaffin granule membranes (CGMs) were used to study the binding characteristics of endogenous $\mathrm{PC} 3$ and its active $\mathrm{C}$-terminal truncated counterpart $(\mathrm{PC} 3 \Delta \mathrm{C})$. Incubation of CGMs with Triton X-100 did not completely solubilise either of these forms of PC3. Moreover, both PC3 and $\mathrm{PC} 3 \Delta \mathrm{C}$ remained associated with detergentresistant membrane microdomains, termed lipid rafts, purified from CGMs. The data raise the possibility that $\mathrm{PC} 3$ and $\mathrm{PC} 3 \Delta \mathrm{C}$ are sorted to the regulated secretory pathway via their association with membrane lipid rafts.

Fournal of Molecular Endocrinology (2001) 27, 107-116

\section{INTRODUCTION}

Prohormone convertase 3 (PC3; also known as PC1) is a member of the subtilisin-like family of endoproteases involved in processing prohormones and neuropeptides that are targeted to the regulated secretory pathway (Seidah et al. 1990, Smeekens et al. 1991). Its expression is restricted to endocrine and neuroendocrine tissues (Seidah et al. 1990, 1991). The basic organisation, common to all proprotein convertases includes an N-terminal signal peptide, a propeptide, a catalytic domain followed by the P-domain and finally a proteinspecific C-terminal fragment (reviewed in Steiner 1998). Cleavage of the signal peptide occurs early in the endoplasmic reticulum (ER) and generates the proprotein zymogen proPC3. Cleavage of the $\mathrm{N}$-terminal propeptide at the amino acid sequence RSKR $^{109}$ is autocatalytic (Goodman \& Gorman 1994) and occurs at neutral $\mathrm{pH}$ conditions typical of the ER (Benjannet et al. 1993, Lindberg 1994, Shennan et al. 1995). The propeptide is thought to be essential for folding of the protease (Shinde \& Inouye 1994) and although cleaved in the ER, it remains associated with the mature $\mathrm{PC} 3$ until later compartments of the secretory pathway, thus acting as an autoinhibitor of $\mathrm{PC} 3$ activity (Boudreault et al. 1998). Further processing of PC3 involves an autocatalytic C-terminal truncation to a $66 \mathrm{kDa}$ form by cleavage at the site $\mathrm{RR}^{618}$ (Zhou \& Lindberg 1993, Lindberg 1994). Cleavage of the C-terminal fragment takes place in later cellular compartments, i.e. the trans-Golgi network (TGN) or the secretory granules (Vindrola \& Lindberg 1992, Lindberg 1994, Zhou \& Mains 1994) where it reaches its maximally active state (Jutras et al. 1997).

PC3 is targeted to the secretory granules in order to process prohormones but the mechanism of targeting is not known. Targeting of proteins into granules may involve the selective aggregation of regulated secretory proteins and their subsequent binding to a membrane component in the TGN or immature secretory granule (reviewed in Arvan \& 
Castle 1998). The present study investigates the membrane association of $\mathrm{PC} 3$ and the role of the proregion and the $\mathrm{C}$-terminal region in this event. The nature of the membrane association was investigated and the data indicate that $\mathrm{PC} 3$, like $\mathrm{PC} 2$, another member of the subtilisin-kexin protease family, interacts with membrane lipid rafts.

\section{MATERIALS AND METHODS}

\section{Chemicals and reagents}

Methionine $(100 \mathrm{Ci} / \mathrm{mmol})$, Rainbow methyl- ${ }^{14} \mathrm{C}$ $\left[{ }^{35} \mathrm{~S}\right]$ labelled protein markers (molecular mass range 14-200 kDa), enhanced chemiluminiscence (ECL) nitrocellulose membranes, and ECL Western blot detection system were purchased from Amersham International (Little Chalfont, Bucks, UK). Rabbit reticulocyte lysate was obtained from Promega (Southampton, UK). SP6 RNA polymerase, bovine serum albumin (DNase/RNase free), nucleotide triphosphates and RNase inhibitor were obtained from Amersham Pharmacia Biotech (St Albans, Herts, $\mathrm{UK}) \cdot \mathrm{m}^{7} \mathrm{G}\left(5^{\prime}\right) \mathrm{ppp}\left(5^{\prime}\right) \mathrm{G}$ cap structure was purchased from New England Biolabs (Hitchin, Herts, UK). A full length cDNA encoding mouse preproPC 3 and a rabbit anti-(mouse PC3) antibody (RS20 B3) were provided by Dr D F Steiner, Howard Hughes Medical Institute, University of Chicago, IL, USA.

\section{DNA manipulation}

The cDNA encoding full length mouse preproPC3, including $5^{\prime}$ and $3^{\prime}$ UTRs (GenBank accession number M58507), was PCR modified to obtain the deletion mutant preproPC $3 \Delta \mathrm{C}$. The forward primer used was $5^{\prime}$-CTTTAGTGAGCGCTC GCT $-3^{\prime}$ targeting the beginning of the $5^{\prime} \mathrm{UTR}$, and the reverse primer was $5^{\prime}$-TCATCAGTCATTCT GGACTGT-3' which generated two stop codons after Asp ${ }^{616}$ just before a dibasic cleavage site $\left(\mathrm{RR}^{618}\right)$, resulting in a mutant that lacks the C-terminal region of PC3. The PCR product, generated using $p f u$ polymerase, was then subcloned into PCR $2 \cdot 1$ vector, sequenced on both strands to ensure no mutations other than the $\mathrm{C}$-terminal deletion, and finally subcloned into pSP64T-R for in vitro transcription and translation in Xenopus egg extract. Full-length preproPC3 was also subcloned into pSP64T-R.

\section{In vitro transcription/translation}

preproPC3 and preproPC $3 \Delta \mathrm{C}$ subcloned into pSP64T-R were linearised with BamHI and in vitro transcribed according to Kreig and Melton (1984). The resulting mRNAs were used for in vitro translations in Xenopus egg extracts prepared following the methodology described in Matthews \& Colman (1991). Briefly, mRNAs were added to $100 \mu \mathrm{l}$ egg extract containing creatine phosphate $(10 \mathrm{mM})$, spermidine $(0 \cdot 2 \mathrm{mM}), 10 \%(\mathrm{v} / \mathrm{v})$ rabbit reticulocyte lysate, and $1 \mathrm{mCi} / \mathrm{ml}\left[{ }^{35} \mathrm{~S}\right]$ methionine, and incubated at room temperature for $2 \mathrm{~h}$. The signal peptide of the resulting proteins is removed during translocation into the microsomal membranes of the extract. The egg extract was then centrifuged at $10000 \mathrm{~g}$ for $15 \mathrm{~min}$ at $4{ }^{\circ} \mathrm{C}$ to pellet the membranes containing the radiolabelled proteins. The pelleted material was washed three times with $10 \%(\mathrm{v} / \mathrm{v})$ sucrose in PBS and resuspended in $80 \mu \mathrm{l} 10 \mathrm{mM} \quad \mathrm{N}$-tris[hydroxymethyl]methyl-2aminoethane-sulphonic acid (TES) $\mathrm{pH} 7 \cdot 0$. The proteins were extracted from the pellet after three sequential freeze-thaw cycles followed by a centrifugation at $10000 \mathrm{~g}$ for $15 \mathrm{~min}$ at $4{ }^{\circ} \mathrm{C}$, and used for membrane-association assays with TGN/ granule-enriched membranes from At'T20 cells.

\section{Membrane-association assays and immunoprecipitation}

TGN/granule-enriched membranes were purified from AtT20 cells as previously described (Varlamov \& Fricker 1996, Blázquez et al. 2000). Sonicated membranes $(\sim 50 \mu \mathrm{g}$ protein in $100 \mu \mathrm{l}$ $0.2 \mathrm{M}$ sucrose in $10 \mathrm{mM}$ buffer (either 2-[Nmorpholino]ethanesulphonic acid (MES), for $\mathrm{pH}$ $5 \cdot 5,6 \cdot 0$ and $6 \cdot 5$, or TES for $\mathrm{pH} 7 \cdot 0$ ) containing $1 \mathrm{mM}$ magnesium acetate) were incubated in the presence of $10 \mu \mathrm{l}$ in vitro synthesised proteins for $1 \mathrm{~h}$ at $4{ }^{\circ} \mathrm{C}$. Membranes were then made $2 \mathrm{M}$ with respect to sucrose and subjected to sucrose gradient centrifugation as described previously (Blázquez et al. 2000) by overlaying with a step gradient of $1.5 \mathrm{M}, 1.0 \mathrm{M}, 0.5 \mathrm{M}$ and $0 \mathrm{M}$ sucrose. After centrifugation, $250 \mu \mathrm{l}$ fractions were collected from the top of the gradient and immunoprecipitated using a sheep antibody raised against amino acids 339-753 of proPC3 coupled to Sepharose beads as previously described (Taylor et al. 1998). When required, samples were adjusted to neutral $\mathrm{pH}$ by the addition of $2 \mathrm{M} \mathrm{NaOH}$ prior to immunoprecipitation. To determine whether peripheral membrane proteins were involved in the binding, TGN-enriched membranes were incubated in $900 \mu \mathrm{l} \quad 0 \cdot 1 \mathrm{M} \mathrm{Na} \mathrm{Na}_{2} \mathrm{CO}_{3}$ or $900 \mu \mathrm{l}$ $10 \mathrm{mM}$ Tris $/ 1 \mathrm{mM}$ magnesium acetate, $\mathrm{pH} 7 \cdot 4$ (controls) for $1 \mathrm{~h}$ at $4{ }^{\circ} \mathrm{C}$. Membranes were then washed twice in $10 \mathrm{mM}$ Tris/1 $\mathrm{mM}$ magnesium 
acetate, $\mathrm{pH} 7 \cdot 4$, prior to incubation with in vitro synthesised proteins.

\section{Detergent extraction, sucrose gradients and Western blot analysis}

Chromaffin granule membranes (CGMs) were isolated from bovine adrenal glands as previously described (Moore et al. 1983, Blázquez et al. 2000). For the detergent extraction experiment, CGMs ( $\sim 0.6 \mathrm{mg}$ protein $/ \mathrm{ml}$ ) were incubated for $1 \mathrm{~h}$ at $4{ }^{\circ} \mathrm{C}$ in TNE buffer $(20 \mathrm{mM}$ Hepes, pH $7 \cdot 4 / 50 \mathrm{mM}$ $\mathrm{NaCl} / 1 \mathrm{mM}$ EDTA) containing $1 \%$ (v/v) Triton $\mathrm{X}-100$. Samples were centrifuged at $125000 \boldsymbol{g}$ for $30 \mathrm{~min}$, supernatants and pellets separated on a $10 \%$ SDS-PAGE, and blotted onto a nitrocellulose ECL membrane. Rabbit anti-(mouse PC3) antibody was used as primary antibody, followed by incubation with horseradish peroxidase-coupled secondary antibody and detected using the ECL system. For the sucrose density gradients, CGMs were incubated in TNE/1\% Triton X-100 buffer as before. The lysate was resuspended to a final $40 \%$ sucrose in TNE and loaded at the bottom of a linear sucrose gradient (5\%-30\%). Following centrifugation for $16 \mathrm{~h}$ at $260000 \mathrm{~g}$, fractions $(1 \mathrm{ml})$ were collected from the top of the gradient, proteins precipitated with chloroform/methanol and analysed by Western blot as described above.

\section{RESULTS}

\section{proPC3 and proPC3 $\Delta \mathrm{C}$ associate with TGN/granule-enriched AtT20 membranes}

The in vitro translation/translocation system used in this study allows the production of $\left[{ }^{35} \mathrm{~S}\right]$ methioninelabelled pro-PC3 and supports autocatalytic maturation to $\mathrm{PC} 3$ at neutral $\mathrm{pH}$ as described previously (Shennan et al. 1995, Scougall et al. 1998). However, the egg extract system does not allow further maturation to the $\mathrm{C}$-terminally truncated form $(\mathrm{PC} 3 \Delta \mathrm{C})$. To determine whether PC3 becomes membrane associated and, if so whether the C-terminal region plays a role in this association, cDNAs encoding wild-type preproPC 3 and a mutant lacking the coding sequence for the last 137 amino acids of the C-terminal region of PC3 (Fig. 1A) were cloned into $\mathrm{SP} 64 \mathrm{~T}-\mathrm{R}$, in vitro transcribed and finally translated in Xenopus egg extracts (Fig. 1B). Wild-type preproPC3 mRNA synthesises a $98 \mathrm{kDa}$ protein corresponding to proPC 3 , having had the signal peptide removed during translocation into the microsomal membranes of the egg extract. Autocatalytic removal of the pro-peptide occurs with a $t_{1 / 2}$ of approximately $10 \mathrm{~min}$ in this system (Scougall et al. 1998) generat- ing the mature $87 \mathrm{kDa} \mathrm{PC} 3$. Translation of the mutant preproPC $3 \Delta \mathrm{C}$ generates two bands corresponding to $78 \mathrm{kDa}$ proPC $3 \Delta \mathrm{C}$, a form which would not occur naturally in vivo, and mature $66 \mathrm{kDa}$ $\mathrm{PC} 3 \Delta \mathrm{C}$, which corresponds to the fully mature, $\mathrm{C}$-terminally truncated form of $\mathrm{PC} 3$ found in vivo.

The mouse corticotrophic cell line, At'T20, known to contain both the regulated and the constitutive secretory pathways, was used as a source of TGN-enriched membranes for membrane binding studies. In vitro synthesised $\left[{ }^{35} \mathrm{~S}\right]$ methionine-labelled proPC 3 and proPC $3 \Delta \mathrm{C}$ bound to $\mathrm{TGN} /$ granule-enriched membranes in a $\mathrm{pH}$-dependent manner (Fig. 2A and B). At $\mathrm{pH} 5 \cdot 5$ most of the proPC 3 and proPC $3 \Delta \mathrm{C}$ were found floating with the membranes in the $1.0 \mathrm{M}$ layer, suggesting that the $\mathrm{C}$-terminal region of $\mathrm{PC} 3$ is not essential for membrane binding. Increasing $\mathrm{pHs}$ ( $\mathrm{pH} 6 \cdot 0,6 \cdot 5$ and $7 \cdot 0$ ) led to a displacement of the in vitro synthesised proteins from the membranes into the soluble fractions (1.5 M and $2 \mathrm{M}$ sucrose). The material found in the pellet corresponds to aggregated proteins. Mature PC3 showed the same pattern of binding as proPC3 (Fig. 2A); however, a different scenario applied to $\mathrm{PC} 3 \Delta \mathrm{C}$, where, although a small proportion of it remained associated with the membranes, the main bulk did not as it could be found in both the $1.5 \mathrm{M}$ and $2.0 \mathrm{M}$ sucrose fractions (Fig. 2B).

Translation of preproPC $3 \Delta \mathrm{C}$ mRNA for a short period of $50 \mathrm{~min}$ resulted in predominantly the precursor form being synthesised with no further processing to the mature $\mathrm{PC} 3 \Delta \mathrm{C}$ (Fig. 3A, lane 1), whereas translation for $2 \mathrm{~h}$ followed by 5 -h chase resulted in $84 \%$ processing of proPC $3 \Delta \mathrm{C}$ into the mature PC $3 \Delta \mathrm{C}$ (Fig. 3A, lane 2). When the protein resulting from the 50-min translation was used in a membrane-binding assay with TGN/granuleenriched membranes from AtT20 cells, all of it, corresponding to proPC $3 \Delta \mathrm{C}$, was bound to the membranes and appeared in the $1.0 \mathrm{M}$ sucrose fraction (Fig. 3B). However, when using the proteins resulting from the $2-\mathrm{h}$ translation/5-h chase in an identical membrane-binding assay, we showed that $93 \%$ of $\mathrm{PC} 3 \Delta \mathrm{C}$ was in the soluble fractions whereas only $7 \%$ was associated with the membranes in the $1 \cdot 0 \mathrm{M}$ sucrose fraction. A faint band corresponding to proPC $3 \Delta \mathrm{C}$ of similar intensity as that of $\mathrm{PC} 3 \Delta \mathrm{C}$ could also be seen in the $1.0 \mathrm{M}$ sucrose fraction (Fig. 3C). This emphasises the importance of the pro-region for membrane association.

To investigate further the nature of the membrane association, AtT20 TGN/granule-enriched membranes were treated with $\mathrm{Na}_{2} \mathrm{CO}_{3}$ to remove peripheral membrane proteins, washed and then incubated with the in vitro translated proPC3, 

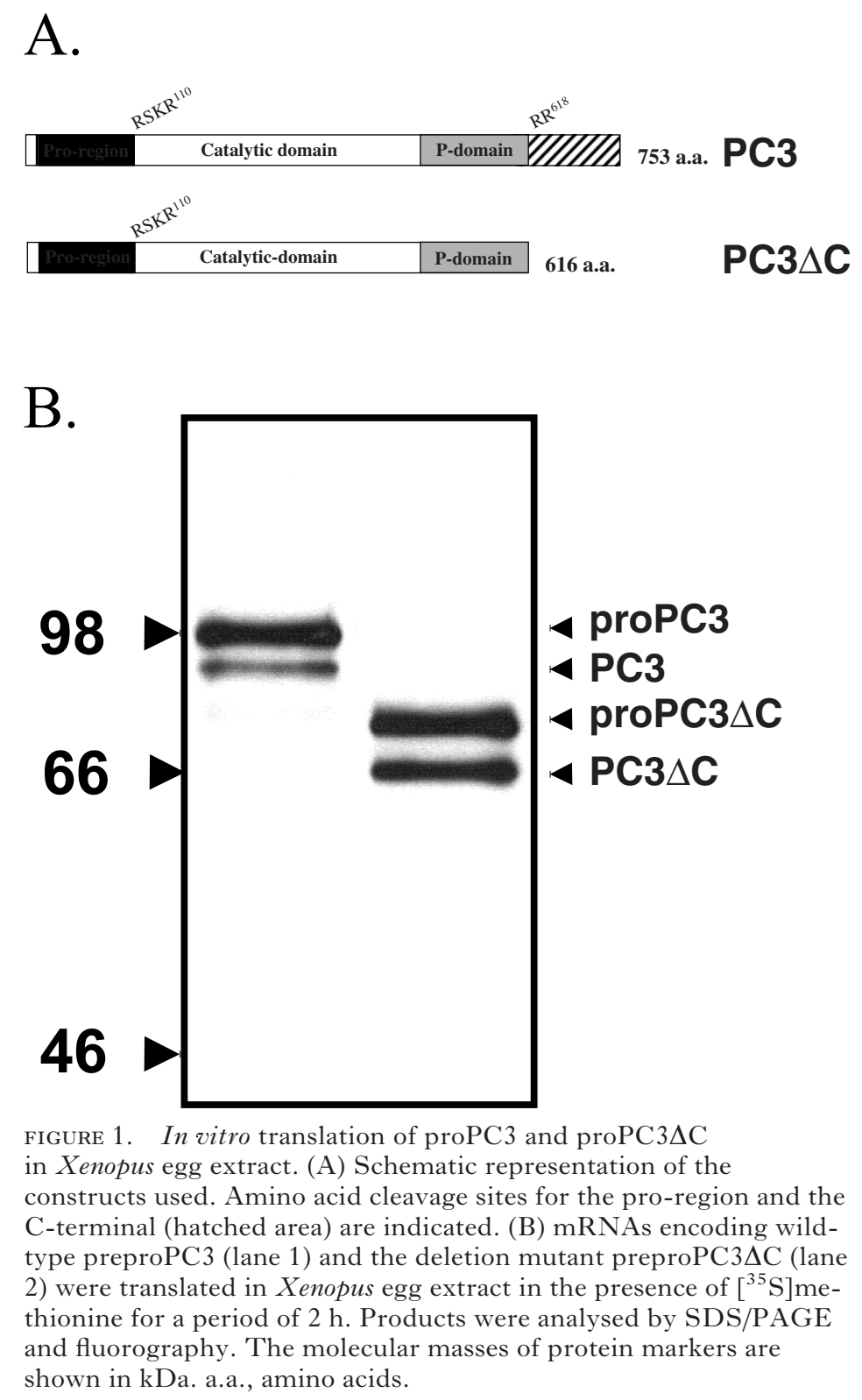

proPC $3 \Delta \mathrm{C}, \mathrm{PC} 3$ and $\mathrm{PC} 3 \Delta \mathrm{C}$. Treatment with $\mathrm{Na}_{2} \mathrm{CO}_{3}$ did not result in any change in the binding properties of any of the proteins (Fig. $4 \mathrm{~A}$ and $\mathrm{B}$ ). The results show that $\mathrm{PC} 3, \mathrm{PC} 3 \Delta \mathrm{C}$ and their precursors do not associate with peripheral membrane proteins from AtT20 cells.

\section{Endogenous PC3 and PC3 $\Delta \mathrm{C}$ associate with lipid rafts from CGMs}

To determine whether PC3 associated with a lipid component of the membrane in vivo, we used
CGMs as a rich source of endogenous secretory proteins such as PC3. After treatment of CGMs with $1 \%$ Triton $\mathrm{X}-100$ for $30 \mathrm{~min}$ at $4{ }^{\circ} \mathrm{C}$, the material was centrifuged, separated into supernatant and pellet and subjected to Western blot analysis. The results show that Triton $\mathrm{X}-100$ did not solubilise endogenous $\mathrm{PC} 3$ or $\mathrm{PC} 3 \Delta \mathrm{C}$, suggesting that both proteins could be interacting with detergent-resistant complexes (Fig. 5A). To determine the effectiveness of Triton X-100 treatment, membranes were stripped and reprobed for chromogranin A $(\mathrm{CgA})$, a regulated secretory 
A
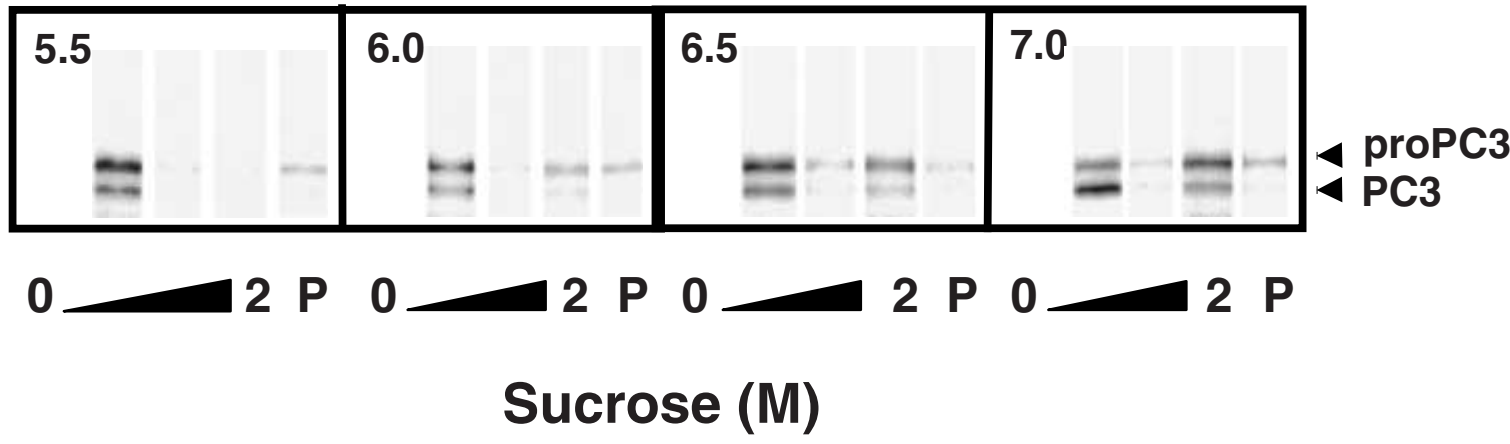

B.
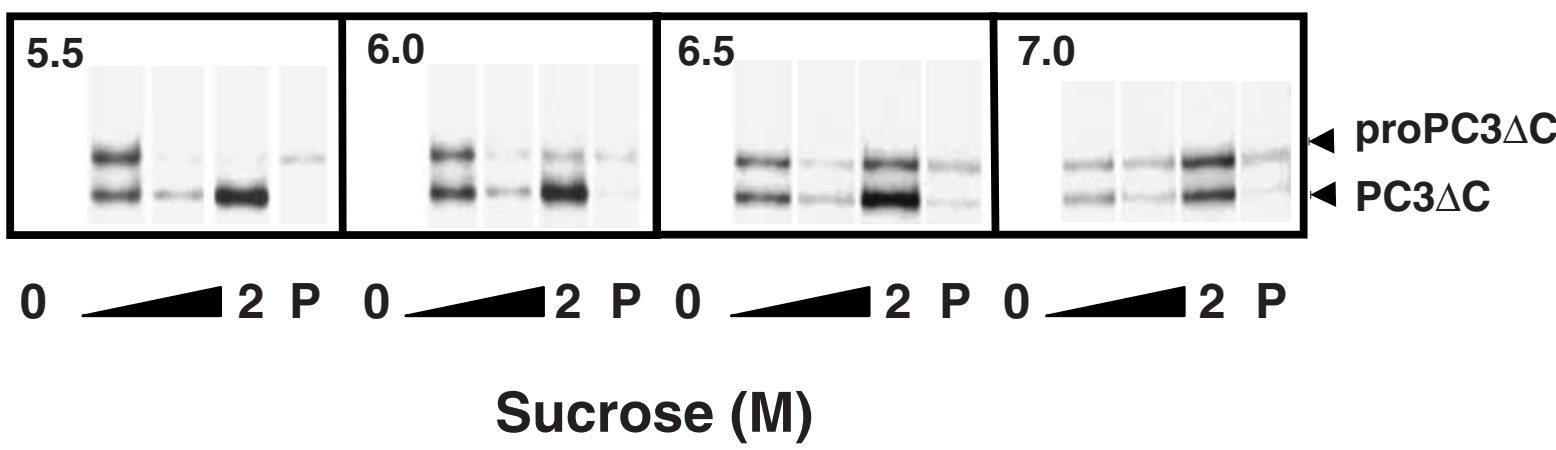

FIGURE 2. Effect of $\mathrm{pH}$ on the association of proPC3, PC3, proPC $3 \Delta \mathrm{C}$ and PC $3 \Delta \mathrm{C}$ with TGN/granule-enriched membranes from AtT20 cells. TGN/granule-enriched At'T20 membranes were incubated for $1 \mathrm{~h}$ at $4{ }^{\circ} \mathrm{C}$ with the in vitro translated $(\mathrm{A})$ proPC $3, \mathrm{PC} 3$, and $(\mathrm{B})$ proPC $3 \Delta \mathrm{C}$ and $\mathrm{PC} 3 \Delta \mathrm{C}$ at a range of $\mathrm{pH}$ values from $5 \cdot 5$ to $7 \cdot 0$. After incubation, the material was adjusted to $2 \mathrm{M}$ sucrose at the appropriate $\mathrm{pH}$ value and subjected to centrifugation $\left(135000 \mathrm{~g}\right.$, for $16 \mathrm{~h}$ at $\left.4{ }^{\circ} \mathrm{C}\right)$ on a step sucrose gradient. Five $250 \mu$ fractions were collected from the top ( $\left.0 \mathrm{M}\right)$ to the bottom $(2 \mathrm{M})$ of the gradient, as well as the pelleted material $(\mathrm{P})$. These were immunoprecipitated using an antibody against amino acids 339-753 of proPC3, resolved by SDS/PAGE and analysed by fluorography. pH values are indicated on the top left corners of the figure composites.

protein previously shown to be removed from CGMs after Triton X-100 treatment (Blázquez et al. 2000, Dhanvantari \& Loh 2000). Triton X-100 treatment resulted in a complete extraction of $\mathrm{CgA}$ from CGMs with $60 \%$ in the pellet of untreated CGMs and $0 \%$ in the pellet of Triton X-100-treated CGMs (data not shown). To assess further the possibility that endogenous $\mathrm{PC} 3$ or $\mathrm{PC} 3 \Delta \mathrm{C}$ could be associating with membranes by binding to lipid rafts, CGMs were treated with Triton X-100 at $4{ }^{\circ} \mathrm{C}$ and subjected to equilibrium centrifugation in a continuous sucrose density gradient (Fig. 5B). After centrifugation, $8 \%$ of $\mathrm{PC} 3$ and $12 \%$ of $\mathrm{PC} 3 \Delta \mathrm{C}$ were found in low-density fractions corresponding to the detergent-insoluble material (fractions 3-5) whereas $33 \%$ of $\mathrm{PC} 3$ and $47 \%$ of $\mathrm{PC} 3 \Delta \mathrm{C}$ remained in the high-density fractions. In addition, the presence of an immunoreactive $74 \mathrm{kDa}$ form of $\mathrm{PC} 3$, a short-lived intermediate in the truncation reaction (Vindrola \& Lindberg 1992) was also found in the detergent insoluble fractions.

\section{DISCUSSION}

Peptide hormones and neuropeptides are initially synthesised as prohormones that undergo posttranslational modification during transport through the cell. Once in the TGN or the immature secretory granule (ISG) many regulated secretory proteins aggregate and associate with membranes, events that may lead to their segregation from constitutively secreted proteins and allow their sorting into the regulated secretory pathway (Arvan 
\& Castle 1998, Blázquez \& Shennan 2000). The present study shows that PC3 binds to TGN/ granule-enriched membranes from AtT20 cells, particularly at acidic $\mathrm{pH}$, with the pro-region having a key role in the binding. Moreover, our results show, for the first time, that both endogenous $\mathrm{PC} 3$ and the enzymatically active $\mathrm{C}$-terminally truncated $\mathrm{PC} 3 \Delta \mathrm{C}$ are present in detergent-insoluble lipid rafts derived from CGMs.

PC3 pro-region has been implicated in the regulation of $\mathrm{PC} 3$ activity acting as an autoinhibitor to delay its action until it reaches the TGN (Zhou \& Mains 1994). Removal of the pro-region is essential for routing and for endoproteolytic activity of both
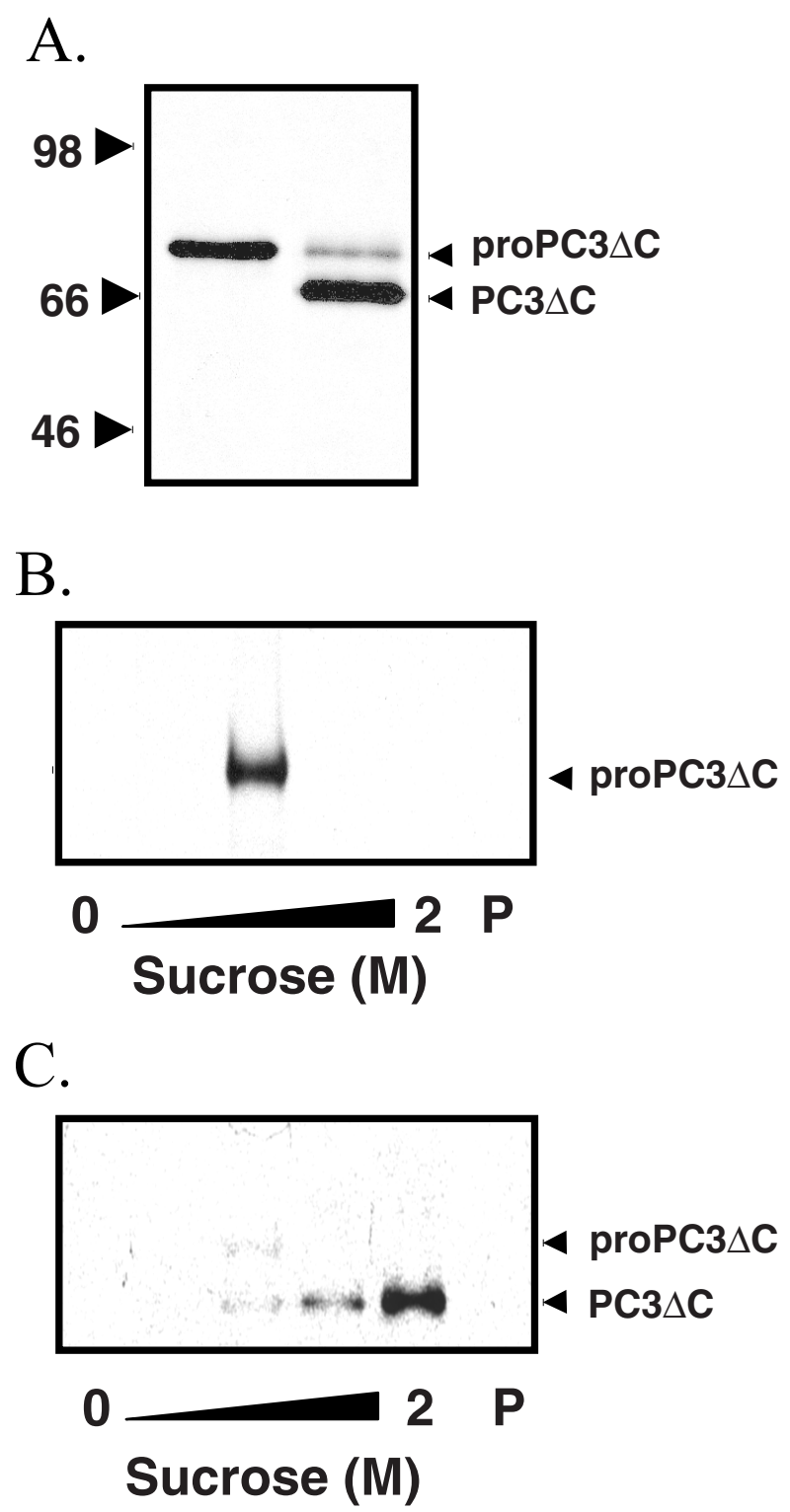

Fournal of Molecular Endocrinology (2001) 27, 107-116
PC2 and PC3 (Zhou et al. 1995a). However, unlike $\mathrm{PC} 2$ for which the importance of the pro-region in membrane association has recently been shown (Blázquez et al. 2000), the role of PC3 pro-region in this event is still unknown. Our in vitro studies show that all molecular forms of $\mathrm{PC} 3$ containing the pro-region (proPC3 and proPC $3 \Delta \mathrm{C}$ ) were able to bind to TGN/granule-enriched membranes from At'T20 cells. Therefore, the $\mathrm{C}$-terminal region of PC3, which contains an amphipathic $\alpha$-helix, is not essential for membrane association. Mature PC3, lacking the pro-region but containing the C-terminal region, was also found associated with membranes. It could be that, as both molecules were found as membrane-bound forms in equimolar concentrations, the presence of the pro-region in proPC3 promotes the aggregation of both proPC3 and $\mathrm{PC} 3$, driving their association with membranes. Another explanation is that in the absence of the pro-region, other sequences in the $\mathrm{C}$-terminal tail can also direct membrane association. The importance of the carboxy terminal region of $\mathrm{PC} 3$ for sorting into the regulated secretory pathway has been studied previously. In PC12 cells, release of a C-terminally truncated mutant, similar to that used in the present study, could be stimulated by $\mathrm{KCl}$, although at lower levels than wild-type PC3, suggesting at least some degree of targeting to the regulated secretory pathway (Zhou et al. 1995b). In At'T20 cells, however, a similar mutant was reported to be secreted largely constitutively with little secretion in response to secretagogues (Zhou et al. 1995a). More recently, it was shown (Jutras et al. 2000) that disruption of the amphipathic $\alpha$-helix in the $\mathrm{C}$-terminal domain of PC3 prevents its targeting to secretory granules. Based on our

FIGURE 3. Binding patterns of proPC $3 \Delta \mathrm{C}$ and $\mathrm{PC} 3 \Delta \mathrm{C}$ to TGN/granule-enriched membranes from At'T20 cells. (A) preproPC $3 \Delta \mathrm{C}$ was translated in Xenopus egg extract for $50 \mathrm{~min}$ (lane 1 ) or for $2 \mathrm{~h}$ followed by a 5 -h chase period (lane 2) and products analysed by SDS/PAGE and fluorography. The molecular masses of protein markers are shown in $\mathrm{kDa}$. TGN/granule-enriched AtT20 membranes were incubated for $1 \mathrm{~h}$ at $4{ }^{\circ} \mathrm{C}$ with proPC $3 \Delta \mathrm{C}$ in vitro translated for $50 \mathrm{~min}(\mathrm{~B})$ or proPC $3 \Delta \mathrm{C}$ in vitro translated for $2 \mathrm{~h}$ followed by a $5-\mathrm{h}$ chase period (C). After incubations, the material was adjusted to $2 \mathrm{M}$ sucrose at $\mathrm{pH} 5 \cdot 5$ and subjected to centrifugation $\left(135000 \mathrm{~g}\right.$, for $16 \mathrm{~h}$ at $\left.4{ }^{\circ} \mathrm{C}\right)$ on a step sucrose gradient. Five $250 \mu \mathrm{l}$ fractions were collected from the top $(0 \mathrm{M})$ to the bottom $(2 \mathrm{M})$ of the gradient, as well as the pelleted material $(\mathrm{P})$. These were immunoprecipitated using an antibody against amino acids 339-753 of proPC3, resolved by SDS/PAGE and analysed by fluorography. 
A.

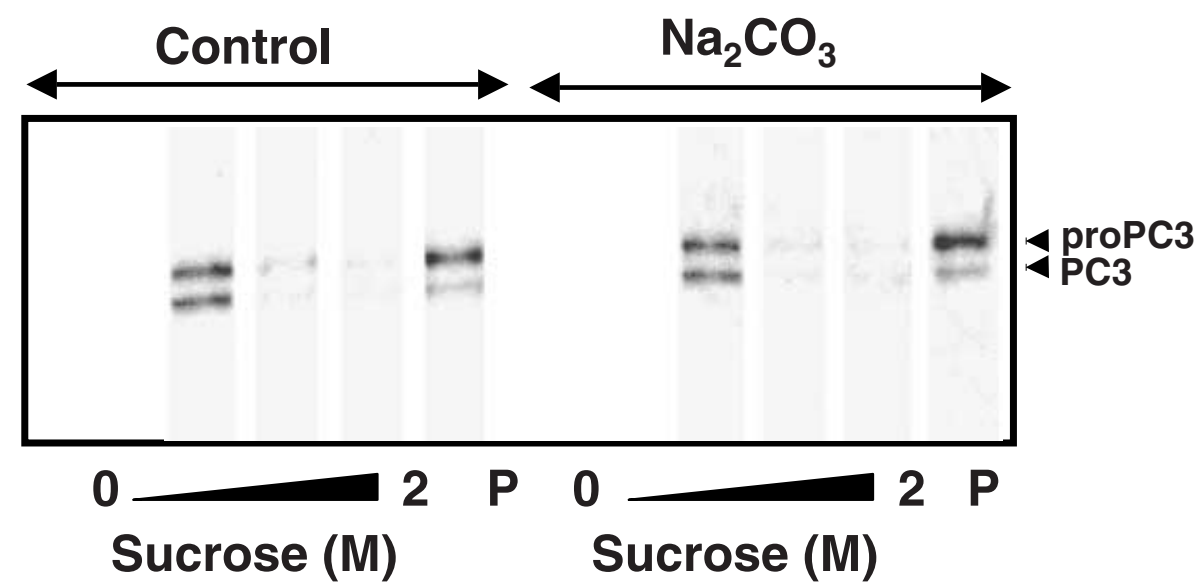

B.

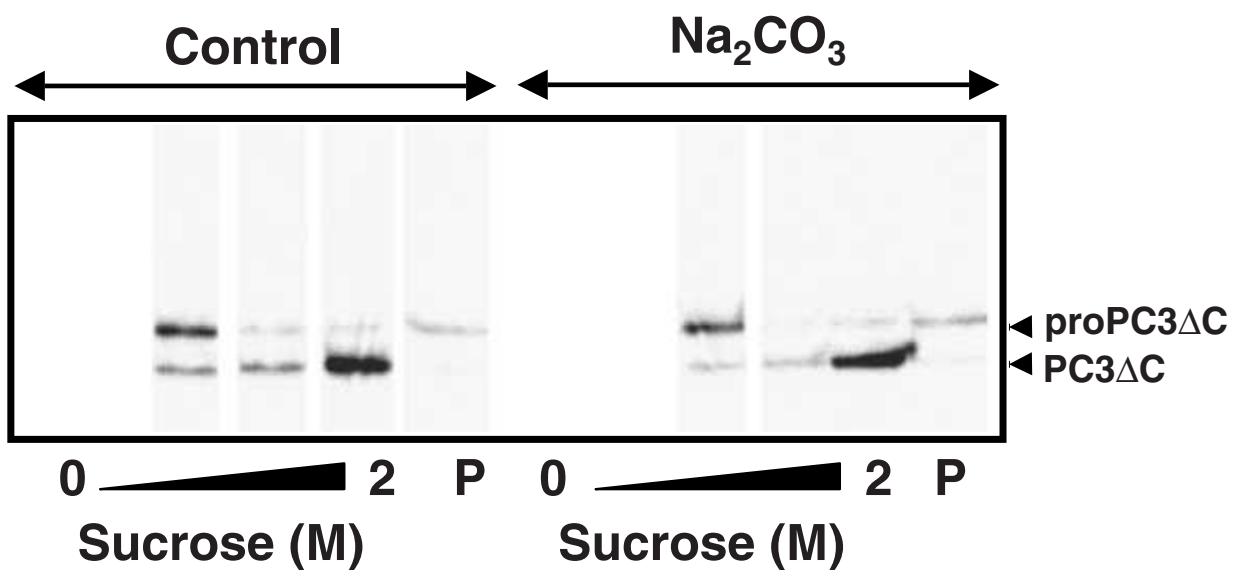

FIGURE 4. Effect of $\mathrm{Na}_{2} \mathrm{CO}_{3}$ on the association of proPC3, proPC $3 \Delta \mathrm{C}$ and their corresponding cleavage products $\mathrm{PC} 3$ and $\mathrm{PC} 3 \Delta \mathrm{C}$ to TGN/granule-enriched membranes from AtT20 cells. TGN/granule-enriched AtT20 membranes were incubated for $1 \mathrm{~h}$ with $0 \cdot 1 \mathrm{M} \mathrm{Na}_{2} \mathrm{CO}_{3}$, washed and further incubated at $4{ }^{\circ} \mathrm{C}$ for $1 \mathrm{~h}$ with the 2 -h in vitro translated (A) proPC3 and $\mathrm{PC} 3$ and $(\mathrm{B})$ proPC $3 \Delta \mathrm{C}$ and $\mathrm{PC} 3 \Delta \mathrm{C}$. The material was then adjusted to $2 \mathrm{M}$ sucrose and subjected to centrifugation $\left(135000 \mathrm{~g}\right.$, for $16 \mathrm{~h}$ at $\left.4{ }^{\circ} \mathrm{C}\right)$ on a step sucrose gradient. Five $250 \mu \mathrm{l}$ fractions were collected from the top $(0 \mathrm{M})$ to the bottom $(2 \mathrm{M})$ of the gradient, as well as the pelleted material $(\mathrm{P})$. These were immunoprecipitated using an antibody against amino acids 339-753 of proPC3, resolved by SDS/PAGE and analysed by fluorography.

results, one could hypothesise that as long as the proregion is not fully removed it will act as a membrane anchor to retain $\mathrm{PC} 3$ as a membranebound form and possibly trigger the aggregation of other PC3 molecules.

Our results show that $\mathrm{PC} 3$ does not bind to membranes via a peripheral membrane protein. Although integral membrane proteins were not investigated in this study, it was previously shown that PC2 interacted with membranes via lipid rafts (Blázquez et al. 2000). Lipid rafts are membrane microdomains, enriched in sphingolipids and cholesterol in a liquid-ordered phase, into which particular proteins partition (Simons \& Ikonen 1997). The vast majority of the work on lipid rafts has involved the use of polarised epithelial and 
A.

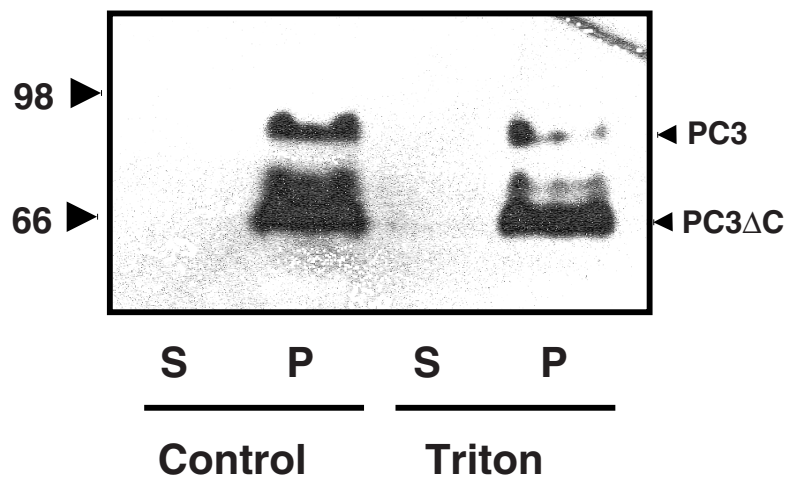

B.

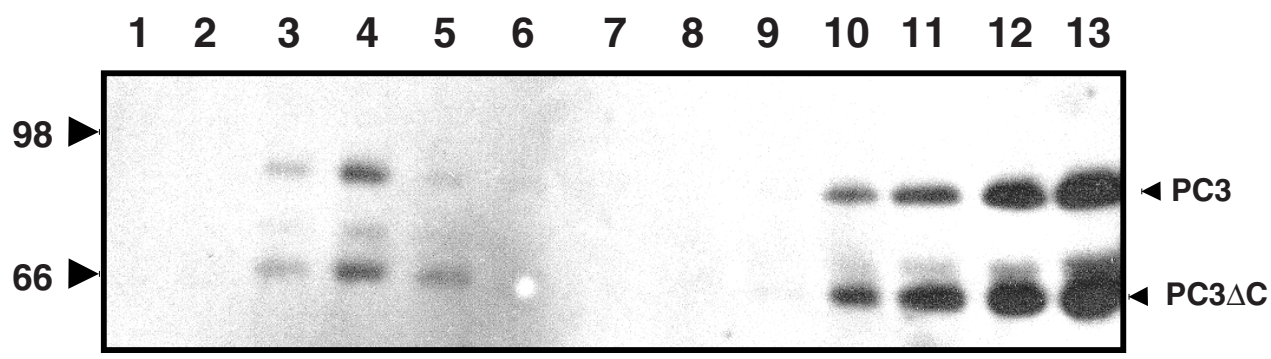

$5 \%$

\section{Sucrose}

$40 \%$

FIGURE 5. PC3 is insoluble in Triton $\mathrm{X}-100$ and floats with detergent-resistant material from CGMs in low-density fractions of a sucrose gradient. (A) CGMs purified from bovine brains were incubated with $1 \%$ Triton $\mathrm{X}-100$ at $4{ }^{\circ} \mathrm{C}$ for $30 \mathrm{~min}$ and supernatants $(\mathrm{S})$ and pellets $(\mathrm{P})$ collected after centrifugation. Samples were analysed by Western blot using an anti-PC3 antibody. (B) After extraction with $1 \%$ Triton $\mathrm{X}-100$ at $4{ }^{\circ} \mathrm{C}$ for $30 \mathrm{~min}$, CGMs were loaded at the bottom of a continuous sucrose gradient $(5-40 \%)$ and centrifuged for $16 \mathrm{~h}$ at $261000 \mathrm{~g}$. One millilitre fractions were collected from top to bottom of the gradient (1-13) and analysed by Western blot using an anti-PC3 antibody.

The molecular masses of protein markers are shown in $\mathrm{kDa}$.

hepatic cells, where they have been implicated in the secretion of proteins to the apical membrane (Scheiffele et al. 1997, Zegers \& Hoekstra 1998). In addition, rafts have also been implicated in axonal sorting in hippocampal neurons (Ledesma et al. 1998) and in the compartmentalisation of proteins involved in signal transduction in T-cells (Stulnig et al. 1998). The similarity between sorting in polarized cells and in neuroendocrine cells has recently been suggested (Blázquez \& Shennan 2000). The main characteristic of lipid rafts is their relative resistance to solubilisation in non-ionic detergents, such as Triton X-100, at low temperatures (reviewed in Simons \& Ikonen 1997, Brown \& London 1998). This results in the isolation of low-density membrane fractions, known to be present in a liquid-ordered phase, that contain cellular raft components clustered together (Simons \& Ikonen 1997, Zegers \& Hoekstra 1998). Our results show that Triton $\mathrm{X}-100$ was unable to completely extract either endogenous PC3 or endogenous $\mathrm{PC} 3 \Delta \mathrm{C}$ from CGMs, suggesting that they might interact with detergent-resistant membranes. Indeed, after flotation assays, both forms of PC3 appeared associated with Triton X-100 detergent-insoluble material found in low density fractions of the gradient corresponding to the lipid rafts. In a similar study, we showed that glycoprotein III, a well characterised raft-associated protein (Brown \& Rose 1992), and also PC2 were 
found in the same fractions of the gradient (Blázquez et al. 2000). Likewise, carboxy peptidase $\mathrm{E}(\mathrm{CPE})$ has also recently been found in lipid rafts isolated from secretory granules (Dhanvantari \& Loh 2000). Interestingly, endogenous PC $3 \Delta C$ remained associated with lipid rafts, but yet $\mathrm{PC} 3 \Delta \mathrm{C}$ appeared not to bind to membranes in vitro. This may indicate either that other regions in the mature protein are responsible for raft association, or that raft association is due to the presence of the pro-region or the $\mathrm{C}$-terminal region that may remain associated with the mature protein for some time after cleavage.

All proteases known to be sorted into the regulated secretory pathway, i.e. PC2, CPE and PC3, along with other proteins, appear associated in high molecular mass aggregates in chromaffin granules (Palmer \& Christie 1992). Posttranslational processing of CPE occurs in the ISGs, possibly with the concerted action of both PC2 and PC3 (Fricker \& Devi 1993), while CPE is needed to remove basic amino acid residues from different prohormones, such as proopiomelanocortin (POMC) or proenkephalin, after PC2 and PC3 processing (reviewed in Fricker 1988). Other propeptides, such as proinsulin, also need the concerted action of PC2, PC3 and CPE to become active (reviewed in Steiner 1998). This might explain the presence of $\mathrm{CPE}, \mathrm{PC} 2$ and $\mathrm{PC} 3$ in the same membrane domain i.e. the lipid rafts, as the rafts may trigger the clustering of these proteins in the TGN/ISG or, alternatively, the clustering of these proteins may trigger raft formation. The importance of raft formation in the targeting of a number of regulated secretory proteins has now been shown, with depletion of sphingomyelin causing a mis-sorting of PC2 (Blázquez et al. 2000), and depletion of cholesterol leading to mis-sorting of CPE and POMC (Dhanvantari \& Loh 2000). It will be interesting to ascertain whether other regulated secretory proteins are found to be raft associated, either directly or via $\mathrm{PC} 2, \mathrm{PC} 3$ or CPE.

Thus, we have shown that the pro-region of PC3 is important for membrane association and that peripheral membrane proteins are not involved. Moreover, mature PC3 and PC $3 \Delta \mathrm{C}$ associate with lipid rafts. From our results, we propose that during transit through the Golgi, PC3 binds to a lipid component of the membrane via the pro-region with which it remains associated. This pro-region, with or without the aid of sequences present in the C-terminal region, might act as a membrane anchor bringing $\mathrm{PC} 3$ into the lipid raft. A decrease in the $\mathrm{pH}$ will result in removal of the pro-region and further maturation of $\mathrm{PC} 3$ into the $\mathrm{C}$-terminally

www.endocrinology.org truncated $66 \mathrm{kDa}$ form. As a consequence, both mature $\mathrm{PC} 3$ and the $66 \mathrm{kDa} \mathrm{PC} 3$ would remain attached to the lipid rafts via other sequences in the molecules, finally being released from the rafts and secreted under neutral $\mathrm{pH}$ conditions.

\section{ACKNOWLEDGEMENTS}

This work was supported by a European Training and Mobility of Researchers Network project ERBFMRXCT960023.

\section{REFERENCES}

Arvan P \& Castle D 1998 Sorting and storage during secretory granule biogenesis: looking backward and looking forward. Biochemical fournal 332 593-610.

Benjannet S, Rondeau N, Paquet L, Boudreault A, Lazure C, Chretien M \& Seidah NG 1993 Comparative biosynthesis, covalent post-translational modifications and efficiency of prosegment cleavage of the prohormone convertases PC1 and PC2: glycosylation, sulphation and identification of the intracellular site of prosegment cleavage of PC1 and PC2. Biochemical Fournal 294 735-743.

Blázquez M \& Shennan KIJ 2000 Basic mechanisms of secretion: sorting into the regulated secretory pathway. Biochemistry and Cell Biology 78 181-191.

Blázquez M, Thiele C, Huttner WB, Docherty K \& Shennan KIJ 2000 Involvement of the membrane lipid bilayer in sorting prohormone convertase 2 into the regulated secretory pathway. Biochemical fournal 349 843-852.

Boudreault A, Gauthier D \& Lazure C 1998 Proprotein convertase $\mathrm{PC} 1 / 3$-related peptides are potent slow tight-binding inhibitors of murine $\mathrm{PC} 1 / 3$ and Hfurin. Fournal of Biological Chemistry 273 31574-31580.

Brown DA \& Rose JK 1992 Sorting of GPI-anchored proteins to glycolipid-enriched membrane subdomains during transport to the apical cell surface. Cell 68 533-544.

Brown DA \& London E 1998 Functions of lipid rafts in biological membranes. Annual Review of Cell and Developmental Biology 14 111-136.

Dhanvantari S \& Loh YP 2000 Lipid raft association of carboxypeptidase $\mathrm{E}$ is necessary for its function as a regulated secretory pathway sorting receptor. Fournal of Biological Chemistry 275 29887-29893.

Fricker LD 1988 Carboxypeptidase E. Annual Review of Physiology 50 309-321.

Fricker LD \& Devi L 1993 Posttranslational processing of carboxypeptidase E, a neuropeptide-processing enzyme, in At T-20 cells and bovine pituitary secretory granules. Fournal of Neurochemistry 61 1404-1415.

Goodman LJ \& Gorman CM 1994 Autoproteolyic activation of the mouse prohormone convertase MPC1. Biochemical and Biophysical Research Communications 201 795-804.

Jutras I, Seidah NG, Reudelhuber TL \& Brechler V 1997 Two activation states of the prohormone convertase PC1 in the secretory pathway. Fournal of Biological Chemistry 272 15184-15188.

Jutras I, Seidah NG \& Reudelhuber TL 2000 A predicted alpha-helix mediates targeting of the proprotein convertase PC1 to the regulated secretory pathway. Fournal of Biological Chemistry 275 40337-40343.

Fournal of Molecular Endocrinology (2001) 27, 107-116 Downloaded from Bioscientifica.com at 04/26/2023 11:50:17AM via free access 
Kreig PA \& Melton DA 1984 Efficient in vitro synthesis of biologically active RNA and RNA hybridization probes from plasmids containing a bacteriophage SP6 promoter. Nucleic Acids Research 12 7057-7070.

Ledesma MD, Simons K \& Dotti CG 1998 Neuronal polarity: essential role of protein-lipid complexes in axonal sorting. PNAS 95 3966-3971.

Lindberg I 1994 Evidence for cleavage of the PC1/PC3 pro-segment in the endoplasmic reticulum. Molecular and Cellular Neurosciences 5 263-268.

Matthews G \& Colman A 1991 A highly efficient, cell-free translation/translocation system prepared from Xenopus eggs. Nucleic Acids Research 19 6405-6412.

Moore HP, Walker MD, Lee F \& Kelly RB 1983 Expressing a human proinsulin cDNA in a mouse ACTH-secreting cell. Intracellular storage, proteolytic processing, and secretion on stimulation. Cell 35 531-538.

Palmer DJ \& Christie DL 1992 Identification of molecular aggregates containing glycoproteins III, J, K (carboxypeptidase $\mathrm{H}$ ), and $\mathrm{H}$ (Kex2-related proteases) in the soluble and membrane fractions of adrenal medullary chromaffin granules. Fournal of Biological Chemistry 267 19806-19812.

Scheiffele P, Roth MG \& Simons K 1997 Interaction of influenza virus haemagglutinin with sphingolipid-cholesterol membrane domains via its transmembrane domain. EMBO Fournal 16 5501-5508.

Scougall K, Taylor NA, Jermany JL, Docherty K \& Shennan KIJ 1998 Differences in the autocatalytic cleavage of pro-PC2 and pro-PC3 can be attributed to sequences within the propeptide and Asp(310) of pro-PC2. Biochemical Fournal 334 531-537.

Seidah NG, Gaspar L, Mion P, Marcinkiewicz M, Mbikay M \& Chrétien M 1990 cDNA sequence of two distinct pituitary proteins homologous to Kex2 and furin gene products: tissue-specific mRNAs encoding candidates for pro-hormone processing proteinases. DNA and Cell Biology 9 415-424.

Seidah NG, Marcinkiewicz M, Benjannet S, Gaspar L, Beaubien G, Mattei MG, Lazure C, Mbikay M \& Chretien M 1991 Cloning and primary sequence of a mouse candidate prohormone convertase $\mathrm{PC} 1$ homologous to $\mathrm{PC} 2$, Furin, and Kex2: distinct chromosomal localization and messenger RNA distribution in brain and pituitary compared with PC2. Molecular Endocrinology 5 111-122.

Shennan KI, Taylor NA, Jermany JL, Matthews G \& Docherty K 1995 Differences in pH optima and calcium requirements for maturation of the prohormone convertases $\mathrm{PC} 2$ and $\mathrm{PC} 3$ indicates different intracellular locations for these events. Fournal of Biological Chemistry 2701402 1407.
Shinde U \& Inouye M 1994 The structural and functional organisation of intramolecular chaperones: the N-terminal propeptides which mediate protein folding. Fournal of Biochemistry 115 629-636.

Simons K \& Ikonen E 1997 Functional rafts in cell membranes. Nature 387 569-572.

Smeekens SP, Avruch AS, LaMendola J, Chan SJ \& Steiner DF 1991 Identification of a cDNA encoding a second putative prohormone convertase related to PC2 in AtT20 cells and islets of Langerhans. PNAS 88 340-344.

Steiner DF 1998 The proprotein convertases. Current Opinion in Chemical Biology 2 31-39.

Stulnig TM, Berger M, Sigmund T, Raederstorff D, Stockinger H \& Waldhausl W 1998 Polyunsaturated fatty acids inhibit $\mathrm{T}$ cell signal transduction by modification of detergent-insoluble membrane domains. Fournal of Cell Biology 143 637-644.

Taylor NA, Jan G, Scougall K, Docherty K \& Shennan KIJ 1998 Sorting of PC2 to the regulated secretory pathway in At'T20 cells. Fournal of Molecular Endocrinology 21 209-216.

Varlamov O \& Fricker LD 1996 The C-terminal region of carboxypeptidase $\mathrm{E}$ involved in membrane binding is distinct from the region involved with intracellular routing. Fournal of Biological Chemistry 271 6077-6083.

Vindrola O \& Lindberg I 1992 Biosynthesis of the prohormone convertase mPC1 in AtT-20 cells. Molecular Endocrinology 6 1088-1092.

Zegers MMP \& Hoekstra D 1998 Mechanisms and functional features of polarized membrane traffic in epithelial and hepatic cells. Biochemical fournal 336 257-269.

Zhou A \& Mains RE 1994 Endoproteolytic processing of proopiomelanocortin and prohormone convertases 1 and 2 in neuroendocrine cells overexpressing prohormone convertases 1 or 2. Fournal of Biological Chemistry 269 17440-17447.

Zhou A, Paquet L \& Mains RE 1995a Structural elements that direct specific processing of different mammalian subtilisin-like prohormone convertases. Fournal of Biological Chemistry $27021509-21516$.

Zhou Y \& Lindberg I 1993 Purification and characterization of the prohormone convertase PC1(PC3). Fournal of Biological Chemistry $2685615-5623$.

Zhou Y, Rovere C, Kitabgi P \& Lindberg I $1995 b$ Mutational analysis of PC1 (SPC3) in PC12 cells. Fournal of Biological Chemistry 270 24702-24706.

RECEIVED 26 February 2001

ACCEPTED 9 April 2001 